\title{
E-LEARNING DALAM PERSEPSI MAHASISWA PENDIDIKAN JASMANI
}

\author{
Romi Cendra ${ }^{*}$, Novri Gazali ${ }^{2}$, Solihin ${ }^{3}$ \\ Universitas Islam Riau, Indonesia ${ }^{1,2,3}$ \\ Email: romicendra@edu.uir.ac.id ${ }^{* 1}$, novri.gazali@edu.uir.ac.id ${ }^{2}$, solihin@ student.uir.ac.id $^{3}$
}

Received: 30 March 2020; Accepted 05 June 2020; Published 18 June 2020

Ed 2020; 5(1): 97-105

\begin{abstract}
ABSTRAK
Penelitian ini bertujuan melihat persepsi mahasiswa Pendidikan Jasmani menggunakan e-learning dalam proses pembelajaran. Jenis penelitian deskriptif kuantitatif. Lokasi penelitian dilaksanakan di Program Studi Pendidikan Jasmani FKIP Universitas Islam Riau. Sedangkan sampel dalam penelitian ini adalah mahasiswa angkatan 2017/2018 yang berjumlah 155 orang, dengan teknik pengambilan sampel total sampling. Tahapan penelitian dilakukan dengan tiga tahap, yaitu: (1) pra lapangan; (2) pekerjaan lapangan; dan (3) analisis data. Teknik pengumpulan data menggunakan angket skala sikap. Metode analisis data yang digunakan adalah statistik deskriptif, statistik ini ditujukan untuk mengumpulkan data, menyajikan data dan menentukan nilai. Hasil penelitian dituangkan dalam 4 kategori yaitu sangat setuju, setuju, tidak setuju, dan sangat tidak setuju. Berdasarkan analisis data yang telah dilakukan, untuk kategori setuju dan sangat setuju sebesar 98\%, ini artinya mahasiswa sangat senang menggunakan $e$ learning sebagai media dalam proses pembelajaran, maka dapat disimpulkan bahwa persepsi mahasiswa tentang penggunaan e-learning sebagai media pembelajaran berbasis teknologi sangat memberikan kemudahan untuk meningkatkan kualitas belajarnya, karena e-learning mudah diakses kapan saja tanpa dibatasi ruang dan waktu. Dari segi konten yang tersedia pada e-learning serta kemanfaatan e-learning dalam proses pembelajaran sangat mempermudah mahasiswa dalam mencari informasi, diskusi secara online dan mengunggah tugas serta bisa mengirit biaya mahasiswa dalam mencetak tugas makalah yang diberikan dosennya.
\end{abstract}

Kata Kunci: Persepsi; E-Learning; Pendidikan Jasmani

\section{E-LEARNING IN PERCEPTION PHYSICAL EDUCATION STUDENT}

\begin{abstract}
This study aims to look at the perception of Physical Education students using e-learning in the learning process. Type of quantitative descriptive research. The research location was carried out in the Physical Education Study Program FKIP Universitas Islam Riau. While the sample in this study was a class of 2017/2018 students totaling 155 people, with a total sampling technique. The stages of the research were carried out in three stages, namely: (1) pre-field; (2) field work; and (3) data analysis. Data collection techniques using attitude scale questionnaire. The data analysis method used is descriptive statistics, these statistics are intended to collect data, present data and determine value. The results of the study are outlined in 4 categories: strongly agree, agree, disagree, and strongly disagree. Based on the data analysis that has been done $98 \%$ of students agree to use e-learning in learning, it can be concluded that students' perceptions about the use of e-learning as a technology-based learning media really provide convenience to improve the quality of their learning, because e-learning is easily accessed anytime without being limited space and time. In terms of the content available on e-learning as well as the usefulness of e-learning in the learning process, it is very easy for students to find information, discuss online, and upload assignments and can save student costs in printing the paper assignments given by their lecturers.
\end{abstract}

Keyword: Perception; E-Learning; Physical Education

Copyright (C) 2020, Journal Sport Area

DOI: https://doi.org/10.25299/sportarea.2020.vol5(1).4721 
How To Cite: Cendra, R., Gazali, N., \& Solihin. (2020). E-Learning Dalam Persepsi Mahasiswa Pendidikan Jasmani. Journal Sport Area, 5(1), 97-105.

\section{PENDAHULUAN}

Seiring dengan perkembangan teknologi, proses pembelajaran juga mengalami kemajuan yang sangat pesat. Pada saat ini orang sudah menggunakan teknologi dalam proses belajar mengajar, salah satu contohnya adalah penggunaan e-learning dalam proses pembelajaran. E-learning merupakan pembelajaran yang pelaksanaanya didukung oleh jasa teknologi seperti telepon, audio, videotape, transmisi satelit atau komputer (Kusmana, 2017). Sedangkan Cidral, Oliveira, Felice, dan Aparicio (2018) menyebutkan bahwa e-learning adalah ekosistem pembelajaran berbasis web untuk penyebaran informasi, komunikasi, dan pengetahuan untuk pendidikan dan pelatihan.

Pada Universitas Islam Riau berbagai inovasi dilakukan untuk meningkatkan kualitas pendidikan dan pembelajaran. Satu di antaranya adalah pengembangan pembelajaran non konvensional berbasis elektronik (e-learning). Pengembangan $e$ learning ini juga memang menjadi kecenderungan dan pilihan karena adanya perubahan dalam kehidupan (Kusmana, 2017). Baik dari Universitas maupun Fakultas, terkhusus untuk FKIP, pimpinan sudah memfasilitasi dosen pengampu mata kuliah setiap program sudi untuk mengikuti pelatihan e-learning, supaya bisa diterapkan dalam proses pembelajaran sesuai dengan mata kuliah yang diampu masing-masing dosen.

Dosen di lingkungan FKIP khususnya pada prodi Pendidikan Jasmani sebagian sudah menggunakan e-learning sebagai pelengkap/pendukung dalam proses pembelajaran, baik dalam bentuk unggah dokumen (RPS, materi perkuliahan) maupun aktivitas perkuliahan secara daring, seperti diskusi dan pengumpulan tugas. Pelaksanaan pembelajaran melalui e-learning perlu untuk dikaji lebih dalam dengan melihat tanggapan mahasiswa terhadap proses pembelajaran menggunakan e-learning, sehingga bisa diketahui persepsi mahasiswa terhadap pembelajaran melalui e-learning ini dan bisa diambil kebijakan oleh pimpinan, baik fakultas maupun universitas dan khususnya prodi Pendidikan Jasmani untuk mengaplikasikan penggunaan $e$-learning dalam proses pembelajaran ataupun perkuliahan di setiap mata kuliah.

E-learning sangat potensial untuk membuat proses belajar lebih efektif, sebab peluang siswa untuk berinteraksi dengan guru, siswa, teman maupun bahan belajarnya terbuka lebih luas (Chandrawati, 2010; Kresnapati, 2018). E-learning merupakan salah satu fasilitas yang dapat membantu berhasil tidaknya proses belajar mengajar (eksternal) dan merupakan salah satu bentuk dari konsep distance learning (Karwati, 2014). Pemilihan dan penggunaan model sistem e-learning yang baik secara otomatis akan mendukung pencapaian tujuan pembelajaran itu sendiri (Setiawan, Hana, \& Waslaluddin, 2014).

Secara garis besar, Siahaan dalam Sari (2017) menyebutkan ada tiga pandangan tentang fungsi pembelajaran berbasis elektronik, yaitu sebagai suplemen, pelengkap atau pengganti. Pertama, dikatakan sebagai suplemen, apabila peserta didik mempunyai kebebasan memilih, kedua, dikatakan berfungsi sebagai pelengkap apabila materi pembelajaran elektronik diprogramkan untuk melengkapi materi pembelajaran yang diterima mahasiswa di dalam kelas, ketiga sebagai pengganti apabila perguruan tinggi di negara-negara maju memberikan beberapa alternatif model kegiatan pembelajaran atau perkuliahan kepada para mahasiswanya. Demir (2015) menyatakan bahwa kesiapan siswa dalam e-learning adalah indikator penting dalam melaksanakan dan menyelesaikan kelas e-learning dengan sukses 
Pada proses pembelajaran menggunakan e-learning, dosen dengan mudah untuk mengunggah catatan perkuliahan dan file presentasi (bahan ajar) ke dalam laman $e$ learning, hal ini merupakan cara yang umum digunakan dan sangat efektif bagi mahasiswa untuk mengakses e-learning secara berkelanjutan (Bath \& Bourke, 2010), sehingga mahasiswa dapat mengulang kembali materi yang telah dipelajari setiap waktu. Dalam sebuah hasil penelitian yang menyatakan bahwa mahasiswa menghendaki pelaksanaan perkuliahan dengan e-learning secara penuh (Muzid \& Munir, 2005). Peran teknologi pendidikan merupakan efek dari perkembangan teknologi yang mempengaruhi akademisi untuk mengubah pembelajarannya (Donnelly \& McSweeney, 2009).

\section{METODE PENELITIAN}

Penelitian ini menggunakan pendekatan kuantitatif, adapun analisis yang digunakan adalah analisis deskriptif (Sugiyono, 2016). Sampel dalam penelitian ini adalah mahasiswa Pendidikan Jasmani FKIP UIR angkatan 2017/2018 yang berjumlah 155 orang, dengan teknik pengambilan sampel total sampling. Instrumen dalam penelitian ini menggunakan angket/kuesioner dan teknik analisis data yang digunakan adalah deskriptif, dengan mempersentasekan pilihan jawaban dari kategori norma yang telah ditentukan sesuai dengan jawaban yang diberikan oleh sampel. Dalam penelitian ini peneliti mengelompokkan persepsi mahasiswa dalam penggunaan e-learning dalam perkuliahan berdasarkan nilai jawaban angket skala sikap. Adapun angket skala sikap dapat dilihat pada tabel 1 .

Tabel 1. Angket E-Learning dalam Persepsi Mahasiswa

\begin{tabular}{l}
\hline Silahkan Pilih Platform E-Learning (Pembelajaran Online) yang Digunakan Saat \\
Perkuliahan \\
\hline - Google classroom \\
- Edmodo \\
- Schoology \\
- Moodle \\
\hline Pengetahuan E-Learning \\
\hline E-learning merupakan sarana pembelajaran secara online \\
E-learning memudahkan mengakses materi perkuliahan dan mengupload tugas \\
E-learning memudahkan dalam menyampaikan informasi \\
Mengintegrasikan pembelajaran offline dengan online \\
E-learning memungkinkan mahasiswa belajar tanpa dibatasi waktu \\
\hline Konten $\boldsymbol{E}$-Learning \\
\hline Sistem -learning menyediakan isi yang sangat sesuai dengan kebutuhan \\
Sistem e-learning menyediakan isi yang bermanfaat untuk perkuliahan \\
Sistem e-learning menyediakan isi yang cukup lengkap \\
Sistem -learning menyediakan isi yang bisa up-to date \\
\hline Aksebilitas $\boldsymbol{E}$-Learning \\
\hline Sistim -learning mudah untuk diakses atau digunakan \\
Pengoperasian sistim -learning stabil dan lancer \\
\hline Kemanfaatan $\boldsymbol{E}$-Learning \\
\hline E-learning mumudahkan mahasiswa dalam mengumpulkan tugas dan diskusi secara online \\
Mengurangi biaya untuk mencetak tugas atau makalah \\
Bisa mengakses materi ataupun tugas sebelum masuk perkuliahan \\
Meningkatkan motivasi belajar \\
Memudahkan untuk belajar mandiri
\end{tabular}




\begin{abstract}
Kepuasan Penggunaan E-Learning
Apakah anda merekomendasikan penggunaan $e$-learning dalam proses pembelajaran?

Setujukah anda menggunakan e-learning sebagai media pembelajaran disaat perkuliahan

Pemberian skor setiap pilihan dari pernyataan skala persepsi mahasiswa ditentukan berdasarkan distribusi jawaban responden atau dengan kata lain menentukan nilai skala dengan deviasi normal (Saifuddin, 2015). Berikut kriteria kategori dapat dilihat pada tabel 2 .
\end{abstract}

Tabel 2. Kategori Norma E-Learning dalam Persepsi Mahasiswa

\begin{tabular}{cc}
\hline Norma & Kategori \\
\hline $3,20-4,00$ & Sangat Setuju \\
\hline $2,80-3,19$ & Setuju \\
\hline $2.40-2,79$ & Tidak Setuju \\
\hline$<2.40$ & Sangat Tidak Setuju \\
\hline
\end{tabular}

\title{
HASIL PENELITIAN DAN PEMBAHASAN
}

Data-data diperoleh dari penyebaran angket kepada mahasiswa Pendidikan Jasmani FKIP UIR mengenai persepsi mahasiswa tentang penggunaan e-learning dalam perkuliahan dengan sampel yang berjumlah 155 orang. Analisis terhadap angket dilakukan berdasarkan indikator-indikator yang telah dibuat dan secara klasikal dari keseluruhan indikator dari persepsi mahasiswa tentang e-learning.

Jenis platform e-learning yang disebarkan melalui angket ada 4 macam sesuai yang biasa digunakan di Indonesia, yaitu google classroom, edmodo, schoology, moodle, dan lainnya. Pada Program Studi Pendidikan Jasmani yang serung digunakan oleh dosen saat perkuliahan sesuai dengan angket yang telah disebarkan kepada sampel yang terbagi dalam beberapa kelas dengan dosennya yang berbeda-beda adalah $100 \%$ pilihan dari sampel menggunakan google classroom. Adapun uraian lengkap terhadap analisis data angket persepsi mahasiswa tentang e-learning disajikan sebagai berikut:

\section{Analisis Pengetahuan Tentang E-Learning}

Analisis mengenai pengetahuan mahasiswa tentang e-learning dalam perkuliahan ini bertujuan untuk melihat pengetahuan mahasiswa tentang e-learning dalam perkuliahan di Program Studi Pendidikan Jasmani FKIP UIR. Berdasarkan hasil dari penyebaran angket kepada sampel dari 4 kategori nilai yang paling terbanyak ada pada kategori setuju dan sangat setuju, maka dapat disimpulkan bahwa pengetahuan mahasiswa mengenai e-learning sudah $97 \%$ mengetahui tentang e-learning. Hasil rekapitulasi datanya disajikan pada tabel 3 .

Tabel 3. Hasil Rekapitulasi Pengetahuan Tentang E-Learning

\begin{tabular}{|c|c|c|c|}
\hline Norma & Kategori & Frekuensi & Persentase \\
\hline $3,20-4,00$ & Sangat Setuju & 59 orang & $38 \%$ \\
\hline $2,80-3,19$ & Setuju & 92 orang & $59 \%$ \\
\hline $2.40-2,79$ & Tidak Setuju & 3 orang & $2 \%$ \\
\hline$<2.40$ & Sangat Tidak Setuju & 1 orang & $1 \%$ \\
\hline & mlah & 155 orang & $100 \%$ \\
\hline
\end{tabular}




\section{Analisis Konten E-Learning}

Analisis mengenai konten e-learning bertujuan untuk melihat bagaimana persepsi mahasiswa tentang konten (isi) yang ada pada e-learning. Berdasarkan hasil dari penyebaran angket kepada sampel dari 4 kategori nilai yang paling terbanyak ada pada kategori setuju dan sangat setuju sebasar 98\%, maka dapat disimpulkan bahwa konten yang ada pada e-learning dalam hal ini platformnya adalah google classroom sangat sesuai dengan kebutuhan dalam perkuliahan, isinya yang lengkap dan bermanfaat serta bisa up-to date dengan materi atau bahan kajian yang diberikan oleh dosen. Hasil rekapitulasi datanya disajikan pada tabel 4.

Tabel 4. Hasil Rekapitulasi Konten E-Learning

\begin{tabular}{cccc}
\hline Norma & Kategori & Frekuensi & Persentase \\
\hline $3,20-4,00$ & Sangat Setuju & 48 orang & $31 \%$ \\
\hline $2,80-3,19$ & Setuju & 104 orang & $67 \%$ \\
\hline $2.40-2,79$ & Tidak Setuju & 3 orang & $2 \%$ \\
\hline$<2.40$ & Sangat Tidak Setuju & - & $0 \%$ \\
\hline & Jumlah & 155 orang & $100 \%$ \\
\hline
\end{tabular}

Kualitas konten merupakan hal yang sangat penting dalam e-learning, serta konten juga harus memiliki keramahan terhadap pengguna (Balaji, Al-Mahri, \& Balaji, 2016; Hernawati \& Aji, 2016).

\section{Analisis Aksebilitas E-Learning}

Analisis mengenai aksebilitas e-learning bertujuan untuk melihat bagaimana persepsi mahasiswa dalam mengakses e-learning dalam perkuliahan, baik saat face to face dengan dosen saat belajar maupun di luar jam perkuliahan. Berdasarkan hasil dari penyebaran angket kepada sampel dari 4 kategori nilai yang paling terbanyak ada pada kategori setuju dan sangat setuju sebesar 98\%, maka dapat disimpulkan bahwa kemudahan akses e-learning sebagai media pembelajaran mudah dilakukan oleh mahasiswa dan juga bisa diakses menggunakan handphone sehingga kapan dan dimana mahasiswa mau akses ke google classroom sangat mudah. Hasil rekapitulasi datanya disajikan pada tabel 5 .

Tabel 5. Hasil Rekapitulasi Aksebilitas E-Learning

\begin{tabular}{cccc}
\hline Norma & Kategori & Frekuensi & Persentase \\
\hline $3,20-4,00$ & Sangat Setuju & 51 orang & $33 \%$ \\
\hline $2,80-3,19$ & Setuju & 100 orang & $65 \%$ \\
\hline $2.40-2,79$ & Tidak Setuju & 4 orang & $3 \%$ \\
\hline$<2.40$ & Sangat Tidak Setuju & - & $0 \%$ \\
\hline & Jumlah & 155 orang & $100 \%$ \\
\hline
\end{tabular}

Aziz, Musadieq, dan Susilo (2013) menjelaskan bahwa kemudahan seseorang dalam mengakses e-learning akan memberikan pengaruh pada sikap pengguna, sehingga membentuk sebuah persepsi seseorang terhadap kemauan dalam menggunakannya.

\section{Analisis Kemanfaatan E-Learning}

Analisis mengenai kemanfaatan e-learning bertujuan untuk melihat bagaimana manfaat e-learning bagi mahasiswa dalam perkuliahan, baik dari segi unggah tugas, mengurangi biaya cetak makalah, mengakses materi sebelum perkuliahan, 
meningkatkan motivasi belajar dan memudahkan untuk belajar mandiri. Berdasarkan hasil dari penyebaran angket kepada sampel dari 4 kategori nilai yang paling terbanyak ada pada kategori setuju dan sangat setuju sebesar 98\%, artinya $e$-learning memberikan manfaat yang signifikan terhadap proses pembelajaran, maka dapat disimpulkan bahwa manfaat media pembelajaran e-learning bagi mahasiswa sangat membantu dalam meningkatkan kualitas belajarnya. Hasil rekapitulasi datanya disajikan pada tabel 6 .

Tabel 6. Hasil Rekapitulasi Kemanfaatan E-Learning

\begin{tabular}{|c|c|c|c|}
\hline Norma & Kategori & Frekuensi & Persentase \\
\hline $3,20-4,00$ & Sangat Setuju & 63 orang & $41 \%$ \\
\hline $2,80-3,19$ & Setuju & 89 orang & $57 \%$ \\
\hline $2.40-2,79$ & Tidak Setuju & 2 orang & $1 \%$ \\
\hline \multirow[t]{2}{*}{$<2.40$} & Sangat Tidak Setuju & 1 orang & $1 \%$ \\
\hline & Jumlah & 155 orang & $100 \%$ \\
\hline
\end{tabular}

\section{Analisis Kepuasan Pengguna E-Learning}

Analisis mengenai kepuasan menggunakan e-learning dalam perkuliahan bertujuan untuk melihat bagaimana kepuasan mahasiswa dalam perkuliahan saat menggunakan $e$ learning sebagai media pembelajaran online. Berdasarkan hasil dari penyebaran angket kepada sampel dari 4 kategori nilai yang paling terbanyak ada pada kategori setuju dan sangat setuju sebesar 99\%, maka dapat disimpulkan bahwa mahasiswa sangat puas dalam menggunakan e-learning pada perkuliahan. Hasil rekapitulasi datanya disajikan pada tabel 7.

Tabel 7. Hasil Rekapitulasi Kepuasan Pengguna E-Learning

\begin{tabular}{cccc}
\hline Norma & Kategori & Frekuensi & Persentase \\
\hline $3,20-4,00$ & Sangat Setuju & 53 orang & $34 \%$ \\
\hline $2,80-3,19$ & Setuju & 100 orang & $65 \%$ \\
\hline $2.40-2,79$ & Tidak Setuju & 2 orang & $1 \%$ \\
\hline$<2.40$ & Sangat Tidak Setuju & - & $0 \%$ \\
\hline & Jumlah & 155 orang & $100 \%$ \\
\hline
\end{tabular}

\section{Klasifikasi E-Learning Dalam Persepsi Mahasiswa Angkatan 2017/2018}

Analisis persepsi mahasiswa tentang penggunaan e-learning dalam perkuliahan secara klasikal bertujuan untuk melihat bagaimana e-learning dalam persepsi mahasiswa Program Studi Pendidikan Jasmani FKIP UIR secara keseluruhan berdasarkan indikator yang telah dibuat. Berdasarkan hasil dari penyebaran angket kepada sampel dari 4 kategori nilai yang paling terbanyak ada pada kategori setuju dan sangat setuju, ini artinya penggunaan e-learning sebagai media pembelajaran berbasis teknologi sangat memberikan kemudahan bagi mahasiswa dalam membantu meningkatkan kualitas belajarnya, karena e-learning bisa diakses tanpa dibatasi ruang dan waktu. Dari segi pengetahuan, konten (isi), aksebilitas, kemanfaatan, dan kepuasan mahasiswa Pendidikan Jasmani FKIP UIR dalam menggunakan e-learning memberikan respon yang sangat baik dalam proses belajar yaitu setuju dan sangat setuju sebesar $98 \%$ dalam penerapan e-learning sebagai media pembelajaran online. Hasil rekapitulasi datanya disajikan pada tabel 8 . 
Tabel 8. Hasil Rekapitulasi Klasifikasi E-Learning Dalam Persepsi Mahasiswa Angkatan 2017/2018

\begin{tabular}{cccc}
\hline Norma & Kategori & Frekuensi & Persentase \\
\hline $3,20-4,00$ & Sangat Setuju & 274 & $35.00 \%$ \\
\hline $2,80-3,19$ & Setuju & 485 & $63.00 \%$ \\
\hline $2.40-2,79$ & Tidak Setuju & 14 & $1.80 \%$ \\
\hline$<2.40$ & Sangat Tidak Setuju & 2 & $0.10 \%$ \\
\hline & Total Frekuensi & $\mathbf{7 5 5}$ & $\mathbf{9 9 . 9 \%}$ \\
\hline & Jumlah Sampel & $\mathbf{1 5 5}$ orang & $\mathbf{1 0 0 \%}$ \\
\hline
\end{tabular}

Setelah angket diperiksa dan dianalisis dapat diketahui bahwa e-learning dalam persepsi mahasiswa pada Program Studi Pendidikan Jasmani FKIP UIR Angkatan 2017/2018 masuk dalam kategori setuju dan sangat setuju sebesar 98\%, ini artinya mahasiswa sangat senang menggunakan e-learning sebagai media dalam proses pembelajaran, maka dapat disimpulkan bahwa persepsi mahasiswa tentang penggunaan e-learning sebagai media pembelajaran berbasis teknologi sangat memberikan kemudahan untuk meningkatkan kualitas belajarnya, karena e-learning mudah diakses kapan saja tanpa dibatasi ruang dan waktu. Berdasarkan hasil penelitian ini, penggunaan e-learning sebagai media pembelajaran online harus diaplikasikan bagi seluruh dosen yang ada di Program Studi Pendidikan Jasmani FKIP UIR. Ini juga didukung oleh penelitian Destriani (2018) pada mata kuliah Kinesiologi, Program Studi Pendidikan Jasmani menemukan bahwa minat belajar mahasiswa menggunakan e-learning dalam pembelajaran sangat baik dengan persentasi $86.36 \%$. Hal ini sebagai bukti bahwa mahasiswa program studi Pendidikan Jasmani FKIP UIR senang memanfaatkan perkembangan teknologi dalam menambah wawasan keilmuannya baik untuk mencari informasi, berdiskusi secara online, upload tugas, dan juga meningkatkan kemampuannya dalam penguasaan media pembelajaran berbasis teknologi.

Sesuai dengan amanat dari Undang-Undang Republik Indonesia Nomor 12 Tahun 2012 tentang Pendidikan Tinggi menjelaskan bahwa untuk meningkatkan daya saing bangsa di era globalisasi maka perguruan tinggi dalam hal ini adalah dosen sebagai tenaga pendidik supaya mampu mengembangkan ilmu pengetahuan dan teknologi di segala bidang keilmuan untuk menghasilkan mahasiswa-mahasiswa yang tidak gagap dengan teknologi (gaptek). Selanjutnya pada Bab 1 Pasal 1 No 4 menerangkan bahwa penerapan dan pemanfaatan teknologi dari disiplin ilmu untuk menghasilkan nilai pemenuhan kebutuhan dan peningkatan mutu kehidupan manusia. Dalam hal ini sudah sangat jelas bahwa pemerintah sangat menitikberatkan penggunaan teknologi terutama di perguruan tinggi sebagai peningkatan kualitas atau mutu dari dosen dan mahasiswanya, seperti penggunaan media pembelajaran berbasis teknologi.

Hal ini didukung oleh penelitian yang dilakukan Najib, Bakar, dan Othman (2017); Saifuddin (2016) menemukan bahwa persepsi mahasiswa dalam penggunaan $e$-learning sangat baik, hal ini dipengaruhi oleh pengetahuan dan pengalaman mahasiswa dalam menggunakan e-learning. Selanjutnya Arjoyo (2015) menyatakan bahwa e-learning mampu meningkatkan kemampuan belajar mandiri dan pemecahan masalah dalam pembelajaran yang dilakukan oleh siswa berdasarkan informasi terkini, kemampuan berpendapat, dan tanggung jawab belajar secara mandiri. Penggunaan layanan pada $e$ learning dapat meningkatkan pengalaman belajar dan kepuasan bagi peserta didik dan pelatih (Chang, 2016). 


\section{KESIMPULAN}

Persepsi mahasiswa tentang penggunaan e-learning sebagai media pembelajaran berbasis teknologi sangat memberikan kemudahan untuk meningkatkan kualitas belajarnya, karena e-learning mudah diakses kapan saja tanpa dibatasi ruang dan waktu. Dari segi konten yang tersedia pada e-learning serta kemanfaatan e-learning dalam proses pembelajaran sangat mempermudah mahasiswa dalam mencari informasi, diskusi secara online, dan mengupload tugas serta bisa mengirit biaya mahasiswa dalam mencetak tugas makalah yang diberikan dosennya.

Hal ini juga sesuai dengan amanat dari Undang-Undang Republik Indonesia Nomor 12 Tahun 2012 tentang Pendidikan Tinggi menjelaskan bahwa untuk meningkatkan daya saing bangsa di era globalisasi maka perguruan tinggi dalam hal ini adalah dosen sebagai tenaga pendidik supaya mampu mengembangkan ilmu pengetahuan dan teknologi di segala bidang keilmuan untuk menghasilkan mahasiswa-mahasiswa yang tidak gagap dengan teknologi (gaptek). Selanjutnya pada Bab 1 Pasal 1 No 4 menerangkan bahwa penerapan dan pemanfaatan teknologi dari disiplin ilmu untuk menghasilkan nilai pemenuhan kebutuhan dan peningkatan mutu kehidupan manusia.

\section{DAFTAR PUSTAKA}

Arjoyo, A. (2015). Implementasi Model E-Learning Pada Mata Pelajaran Pendidikan Agama Islam (PAI) di SMA N 6 Bengkulu Selatan. Institut Agama Islam Negeri Bengkulu.

Aziz, A. L., Al-Musadieq, M., \& Susilo, H. (2013). Pengaruh Kemudahan Penggunaan Terhadap Kemanfaatan Pada Sikap Pengguna E-Learning. Jurnal Administrasi Bisnis (JAB), 6(2), 1-7.

Balaji, R. D., Al-Mahri, F. A., \& Balaji, M. (2016). A Perspective Study on Content Management in E-Learning and M-Learning. Computer Science, 1-7.

Bath, D., \& Bourke, J. (2010). Getting Started with Blended Learning. Mount Gravatt: Griffith University.

Chandrawati, S. R. (2010). Pemanfaatan e-learning dalam pembelajaran. Jurnal Cakrawala Kependidikan, 8(2), 172-181.

Chang, V. (2016). Review and discussion: e-learning for academia and industry. International Journal of Information Management, 36(3), 476-485. https://doi.org/https://doi.org/10.1016/j.ijinfomgt.2015.12.007

Cidral, W. A., Oliveira, T., Felice, M. Di, \& Aparicio, M. (2018). E-learning success determinants: Brazilian empirical study. Computers \& Education, 122, 273-290. https://doi.org/10.1016/j.compedu.2017.12.001.This

Demir, O. (2015). The investigation of e-learning readiness of students and faculty members: Hacettepe University, Faculty of Education Example. Hacettepe University. 
Destriani. (2018). Minat pembelajaran menggunakan e-learning mata kuliah kinesiologi pada mahasiswa. JUMANJI, 2(1), 63-70.

Donnelly, R., \& McSweeney, F. (2009). Applied E-learning and E-Teaching in Higher Education. New York: Information Science Reference.

Hernawati, E., \& Aji, P. (2016). Perancangan dan penerapan konten e-learning melalui learning management system dalam meningkatkan motivasi belajar. Journal of Information Systems Engineering and Business Intelligence, 2(1), 23-32.

Karwati, E. (2014). Pengaruh pembelajaran elektronik (e-learning) terhadap mutu belajar mahasiswa. Jurnal Penelitian Komunikasi, 17(1), 41-54.

Kresnapati, P. (2018). Tantangan SDM Melalui Pengembangan Teknologi dalam Pembelajaran PENJAS di Sekolah. In Prosiding Seminar Nasional Keindonesiaan III "Penguatan SDM di Era Disrupsi Teknologi Melalui Pendidikan" (pp. 441446). Semarang: Universitas PGRI Semarang.

Kusmana, A. (2017). E-learning dalam pembelajaran. Jurnal Ilmu Tarbiyah dan Keguruan, 14(1), 35-51.

Muzid, S., \& Munir, M. (2005). Persepsi Mahasiswa Dalam Penerapan E-Learning Sebagai Aplikasi Peningkatan Kualitas Pendidikan (Studi Kasus Pada Universitas Islam Indonesia). In Seminar Nasional Aplikasi Teknologi Informasi (pp. 27-34).

Najib, H. M., Bakar, N. R. A., \& Othman, N. (2017). E-pembelajaran dalam kalangan pelajar di sebuah institusi pengajian tinggi Selangor. Attarbawiy: Malaysian Online Journal of Education, 1(1), 74-82.

Saifuddin, A. (2015). Sikap Manusia Teori dan Penerapannya. Yogyakarta: Pustaka Pelajar.

Saifuddin, M. F. (2016). E-learning dalam persepsi mahasiswa. Jurnal VARIDIKA, 29(2), 102-109.

Sari, I. P. (2017). Implementasi pembelajaran berbasis e-learning menggunakan claroline. Research and Development Journal Of Education, 4(1), 75-87.

Setiawan, W., Hana, M. N., \& Waslaluddin. (2014). Analisis Penerapan Sistem ELearning FPMIPA UPI Menggunakan Technology Acceptance Model (TAM). Jurnal Pengajaran MIPA, 19(1), 128-140.

Sugiyono. (2016). Metode Penelitian Kuantitatif, Kualitatif dan R\&D. Bandung: PT Alfabeta. 